\title{
A Sociological Study of the Form and Content Produced in the Social Media of the International First Rank Universities
}

\author{
Sina Eskandari ${ }^{1} \&$ Saeed Rezaei Sharifabadi ${ }^{2}$ \\ ${ }^{1}$ Alzahra University, I. R. of Iran, Iran's National Elites Foundation, Iran \\ 2 Alzahra University I. R. of Iran, Iran \\ Correspondence: Sina Eskandari, Alzahra University, I. R. of Iran, Iran's National Elites Foundation, Iran
}

Received: August 23, 2020 Accepted: January 3, $2021 \quad$ Online Published: January 21, 2021

doi:10.5539/res.v13n1p43 URL: https://doi.org/10.5539/res.v13n1p43

\begin{abstract}
This research is an attempt to deal with the role of social media in the promotion of the name of universities at international scene. Thus, the analysis of the structure and contents of productions will be the subject of discussion in this research. It should be noted that each social media has unique features and in order to get an ideal result, it is necessary to have knowledge about the details and sociology of the use of social media by users. Having identified the responsibilities which are assigned by propagation designers of universities to department, it will be possible to plan a comprehensive and unique program for the activities of different departments of university, so that in the event of demand, each unit can have an influential role in introducing the university in a professional form.
\end{abstract}

Keywords: media, university, propagation, social media, public relations

\section{Research Background}

Alicia Rodriguez Gascon, a media scholar has allocated his thesis on the role of social media as an instrument for publicizing the Spanish universities. He believes that using the power of social medias, today universities have more presence in the students' life and have been able to establish a close relation with them and present a more sincere image of university to the addressees. Knowing that in the other side of virtual user account, a sympathetic person is orienting the addresses rather than instructed robot, it has caused a better interaction to take shape between the addresses and authorities of the university. (Gascón, 2017)

Morgan Glucksman has allocted his study on the topic of the significance of virtual media in the continuation of the life of a company or an international brand. He believes that today if a company limits its marketing activities to traditional methods like billboard and propagations in the press, will definitely face defeat. He considers the role of influencers of social media like nuts and bolts of the industry of propagation. The analytical part of the article deals with the knowledge about three favorite social medias including Instagram, YouTube and Twitter and has explained the atmosphere of using and reasons for the popularity of each comprehensively. (Glucksman, 2017)

BaharBicen Aras and HuriyeGolaklar have allocated their research on the study and review of a university department and its role in the social media in developing the name of the department. These researchers believe that departments use the social media as a unit of public relations, disseminate information about the activities and events and also observe and measure the views and comments of the users.

(Bahar Biçen Aras, 2015)

"We use social media to answer students' questions, listen to their opinions and take action, so that they understand that they are being heard". - Stephen Boucher, Director of Marketing and Communications, Southern New Hampshire University

\section{Statement of the Problem}

In this article, i.e. Using YouTube Video to promote university: A content analysis, 140 universities from 14 countries have been observed and studied with regard to the topic of university propagation.

In this research, the activities of universities in social media have been justified for two reasons: 
1. Downsizing the states will lead to the independence of universities and universities should supply their own budget through investment on foreign students.

2. Universities should absorb foreign students in order to use the governmental budgets.
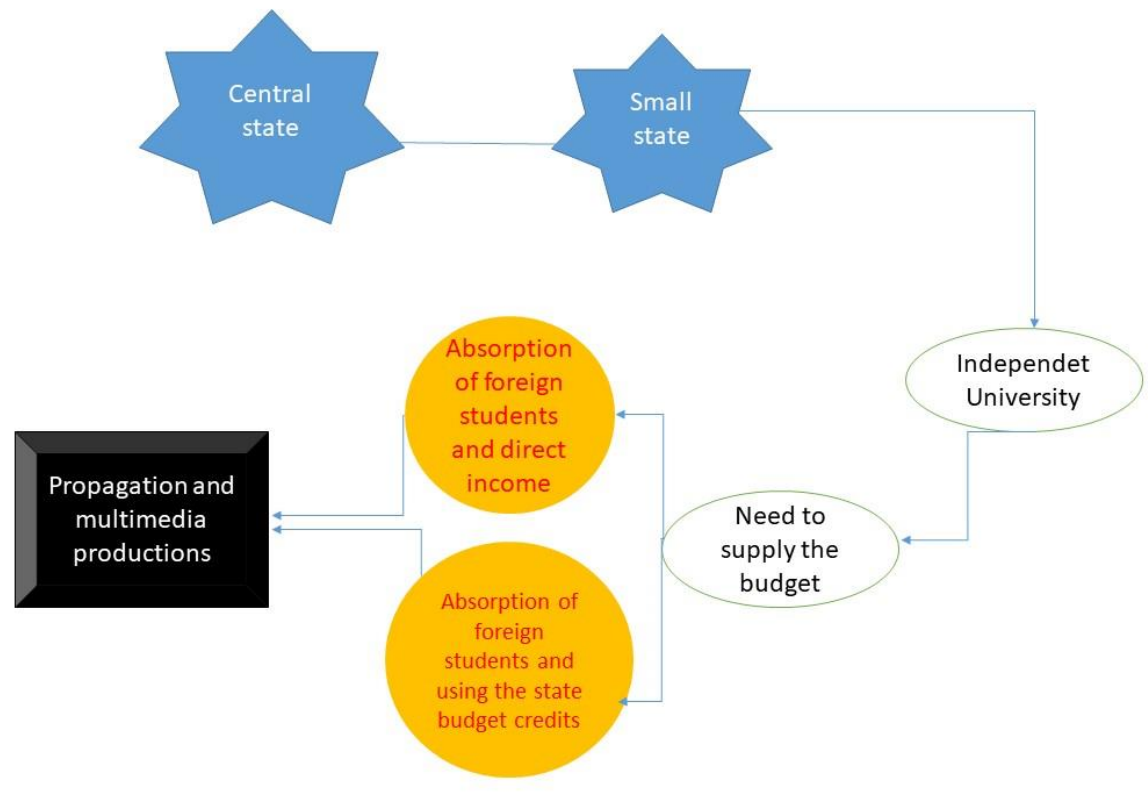

Diagram 1. Reasons for the inclination of universities to produce multi-media productions

Universities have tended towards social media to achieve economic autonomy and gain reputation at international level. It is not possible to name one media as the meeting place for university people. However, the studies show that the addresses in some of the applications enjoy a higher level of education but it is not possible to limit the public views to one application.

With a simple search in the social media of top universities in the world, it will be possible to find out their unique structures and strategies. Having shifted their own virtual networks (medias) to experts and or trained the skilled staffs, universities try to minimize the distance between university and students and move out from the traditional relations. Thus, social media of universities are not merely a unilateral information portal and are considered a circle to measure the public view and communication with the addressees too.

\section{Research Methodology}

In this research, in addition to library and internet studies, the multi-media production were reconsidered and analyzed. The social medias of face book, LinkedIn, Instagram and YouTube were also observed and having collected the produced samples, the type of products were discussed.

Firstly, I pursued to find necessary sources for starting the research. I noticed that this subject has not been investigated earlier. Thus, I chose the observational method and classified the social media vis-à-vis the popularity and rate of content production. I was systematically searching for finding knowledge about the characteristics of the best platform to present publicizing videos in universities.

Having watched hundreds of videos which had been broadcasted in the cyberspace, formal websites and followers' weblogs, I could classify the videos and their method of production. Thus, through technical analysis of each of them, I examined them from the viewpoints of audio-visual feature, idea and objective of its production in details and I could specify the impact of each of them by analyzing the comments in social media and asking from the viewers and the impact which they leave on them.

As for the topic of motion graphics, I reviewed the activities of a number of different universities and analyzed some samples of productions of the unit of Public Relations in universities. In the process of conducting this research, one of my main obstacles was the lack of sufficient academic sources to study the problem. Many of the commercial or artistic sites were presenting some information about the method of production of videos or the impact of commercial videos on viewers, but the lack of access to sufficient sources made the researcher spend much more time to know the basic concepts. In other words, this research can be considered among the basic researches. 


\section{Review of the Literature}

Google site, the most important online search engine, refers the investors and in particular the designers of startups to the concept of Zero Moment of Truth (a moment that the spark of purchase or use of production and or content is trigged in the addressee's mind) (Aichner, 2012), which means if producers wants to have its brand to be well known, they should observe a number of principles in the beginning of the job:

1. They should have a physical or electronic brochure or catalogue at hand on the related product.

2. The assumed questions by addresses on the content, product or services should be responded.

3. Info graphic and short videos should be used in order to educate and define the key words and products.

4. If possible, a comparison to be made with other rivals and the positive points to be announced.

Rebeca Cordero has reviewed the policies of universities and believes that the first step for activity in social media is to know the medias and their addressees. In the second stage, with the completion of profile, user account should be created in each of the concerned medias. The page which does not have a content, will not have a chance to absorb the followers and visitors. For this important objective, in the profile, the advantages of following a social page for the addresses should be talked about. In academic and university topics, if there is not still a framework in mind, it is necessary to refer to the virtual pages of rivals and colleagues to use their experiences. Administrators of virtual pages should use analyzer sites such as www.Buzsummo.com to gain knowledge about the favorability of subjects and needs of the addresses to avoid paving a walked path. Through searching the key words related to each industry, the number of favorite articles in Face Book, Twitter and Instagram will be shown. In this way, it is possible to learn which subjects are interesting and which subjects are insignificant. After production of content, we reach to the stage of communication with the addressee. It is possible to have a constructive interaction with the addressees through different methods, such as following the pages of rivals, academic individuals, students and so on to responding to the addresses below the published posts, responding to the direct messages. It is also possible to encourage those who are not members in these medias by sending an invitation to use this space. Republication of materials related to the subject of activity and using the related hashtags can cause interest in the visitors to visit the pages in virtual Medias. (Rebeca Cordero, 2016)

With the breaking of monopoly of production of contents in virtual atmosphere, it not any more possible to refer to the basic and old theories of social media. For example, the Hypodermic needle model which was proposed in the Cold War and used to consider the addressee as a passive element in accepting the contents of medias, has basically no position in this discussion, since the today's addresses are not the receivers of yesterday's passive messages and through instruments and tribunes which they have in the virtual space can criticize and review the multimedia products and share them with other addressees. (Guggenheim, 2011)

Among the more recent theories on social media, the Agenda-setting theory puts forth the impact of media on cognition and attitude of the addressee and determining the mental priorities with magnifying some of the incidents within the framework of news and reports. (Zain, 2014)

According to Castles theory, virtual atmosphere is a democratic environment, because it has overthrown the patriarchal system by moving out the tribune from the control of a specific current and has brought about an opportunity for the presence in the virtual community for everybody. With democratization of atmosphere and reminding this point that media cannot dictate how to think, it emphasized the agenda-setting theory of the role of media in limiting the selection of addressees. In other words, it engineers the producers of tastes and presents the packages to the addressee in a limited form.

\section{Discussion}

University is in need of a united strategy in the domain of activities in social Medias. The strategy of social media should be planned in form of a repeatable method, holding a concept and a bed rock in dealing with addressees. The adoption of a united strategy will give this opportunity to a university to put forth its credit, job opportunities and brand. (Zain, 2014) 


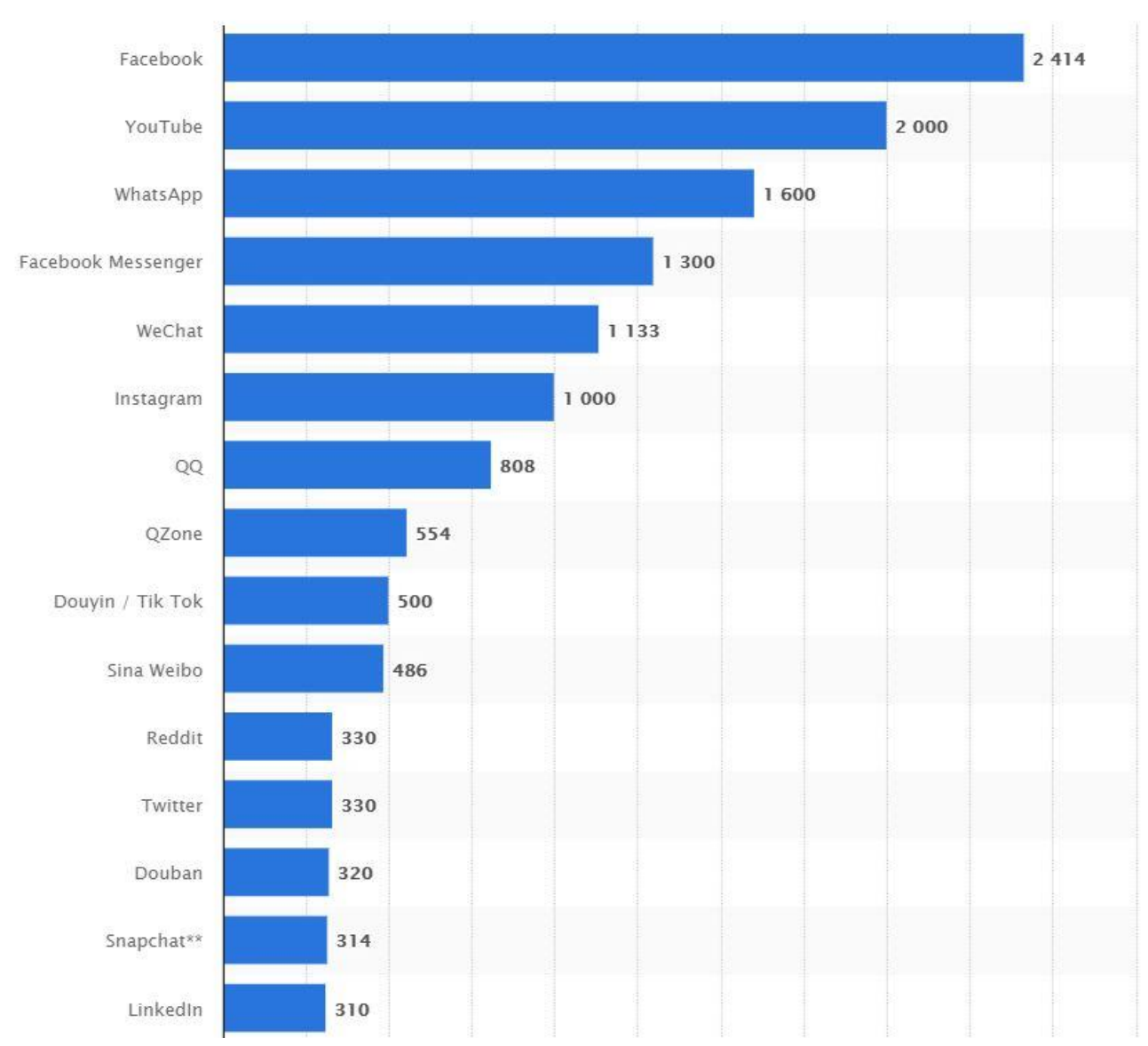

Statistics of the users of social media and messengers in 2019 by million people.

In order to use the strategy of presence in social media, it is necessary to specify the medium or the very communicative way. The above statistics show the significance of each of social networks in a global scale. (users, 2019)

\section{Contents of multimedia products of universities}

The multimedia products of universities can be divided into four categories:

1. Products of classic propagations

2. Student-centered products

3. Motion graphic products

4. Infographic products 


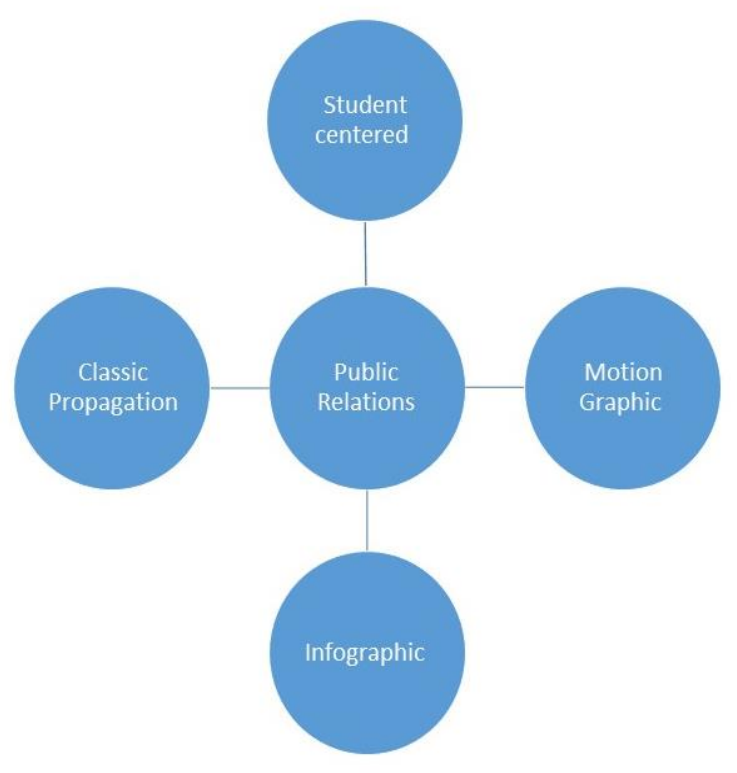

Diagram 2. Multimedia products of universities

\section{Products of classic propagations}

In this branch, publicizing video with cinematic literature is produced in form of a report which includes the following plans:

Activities of faculties, academic spaces of university, recreational and sport spaces, welfare facilities, international students, history of the university, place of establishment of university, significance of university or the city, some statistics of the graduates, students and faculty members.

Also certain slogans as the propagation mottos of university is presented in the beginning and end of the publicizing film. In the classic propagation film mainly the professional teams of film making are used in order to present a better display of the university. The views are shot by using professional portable devices and mainly one or many narrators narrate the slogans and facilities of the university. This branch can be considered as the formal language of the university. For this purpose, each university should present a classic film of its own activities and facilities far from the day taste. It is worth mentioning that the propagation classic film should be uploaded in the main page of the websites of universities and to be used in ceremonies, celebrations and also for the sake of publicizing the university.

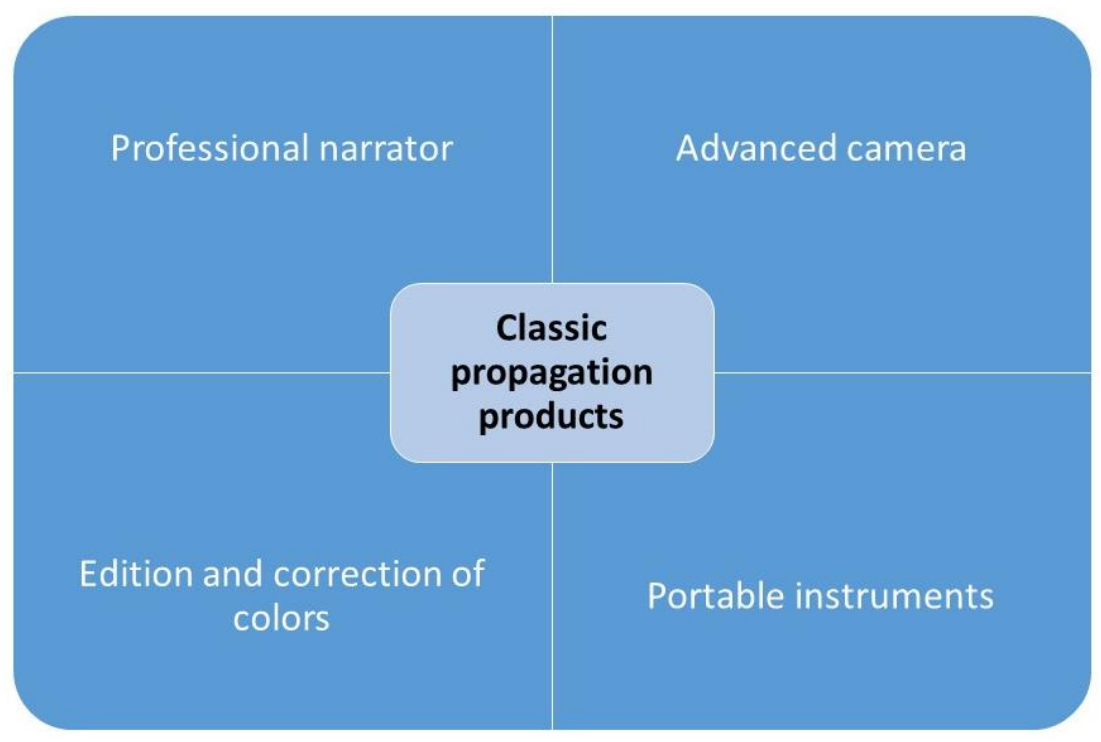

Diagram 3. Production of classic propagations 
"We want to engage and make sure the student voices are heard ... It's all about authenticity". Jason Boucher, Social Media Coordinator, University of New Hampshire

This section should be divided into two parts:
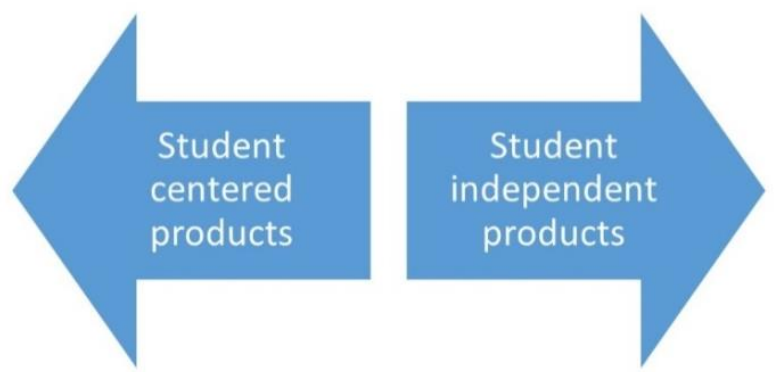

Diagram Explanation 4: Student-centered products

\section{Student independent products}

In this style of production, students themselves narrate a personal narration of life as a student in academic environments. The addressees of this style of productions are the users of virtual networks such as Instagram and YouTube, the students who intends to study in the related university or have similar problem or experience. In this style of production, there is no need to professional tools and devices. Using a mobile camera and at most a stabilizer, students begin to produce contents and they become so called, "tour leader" for the addressee to know the faculties and university or showing the facilities of university complex. These types of productions are close to the literature of journalists and Paparazzi [Paparazzi are independent photographers who take pictures of high-profile people, such as actors, athletes, politicians, and other celebrities, typically while subjects go about their usual life routines]. In the literature of multimedia products, these individuals are close to vloggers or weblog writing tourists. [Vlogger: A vlogger is somebody who creates and uploads a video blog].

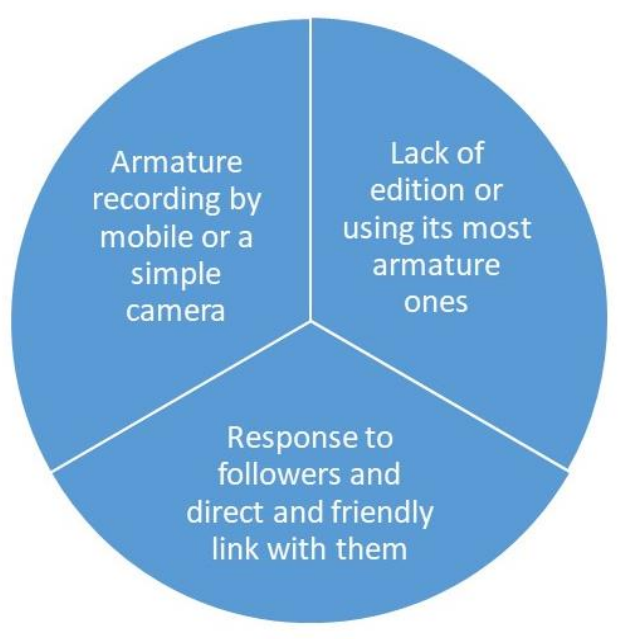

Diagram 5. Student independent products

Reviewing some samples of videos produced by students, we will learn the significance of title writing as one of the basic pillars of news writing:

A day in my life as college student in LA (what I eat /my workout) liv Vargus

(Vargus, 2017)

In this video, the student takes images of his one-day experience in university and expresses the positive and negative points.

Oxford student life, England diaries

(Thefannie, 2018)

In this video, we observe the daily life of a student in university from the morning till the evening. A fast visit to the 
university and life style in the university.

Studying abroad in Rome!

(Sison, 2018)

Images have been taken from the moment of exit from house up to reaching the Rome and studying in university and the style of web loggers and web log writing touts have been observed.

10 things to know before coming to university of San Diego

(Ford, 2019)

In this video, 10 main points before starting education in the university has been stated in the most simple way. Student has turned on the camera and has expressed his concerned materials to the camera without any edition.

The most outstanding feature of student independent products is the presence of the student as the author, director and producer. This style of production is economic and due to lack of using video editions, professional camera and using the simplest instruments makes the viewer have easily trust on the policy of the video.

Among the professional medias, the literature of multimedia productions moves towards simplicity. For example, interviews are less made at the back of a desk and with performance of rituals. Katrin Bpunkt, a T.V. programmer, produces a program entitled "in the bed with book and music in her You Tube channel and makes interviews in the personal bed of her subject. She tries to minimize the limit and border of the space between the addressee and subjects. In bed with Adam and Green ( Binki Shapiro, 2014), sincerity finds meaning in physical proximity and even if there is no right words in the words of the subject, but it becomes more believable, since he has given permit to the viewer to reach to the closest distance with him and this means that he has nothing to hide.

Emission of relations and locating the armature camera in various angles and interview without edition is a new method of corresponding and media planning which has become popular these days. Games Corden has also presented this model in The Late Show. (Bieber, 2015). Thus, the omission of physical distance from the back of a round table to the closest distance is interpreted as a further sincerity.

\section{Participatory productions of university and student}

In this style of productions, university through extending support to students and mainly by writing scenario by students, introduces the university. This style of productions has certain priorities as compared with the classic film. There, a professional narrator is not used. The sense of sympathy between student and addresses who are mainly students and or those interested in studying in university is reinforced. A combination of beautiful visual manifestations and sincerity of students is presented to the addressee. However, this style of productions as compared with independent student productions has some shortages and that is avoiding of displaying the whole reality. University supports a package which is in line with its own interests. The Department of Public Relations usually in collaboration with students and with the inclusion of incenting advantages, encourages the students to participate in the production of contents. Naturally, if negative points are expressed by students in a critical way, they will not pass through the edge of the blade of censorship of university. It should be noticed that all multimedia contents of universities are for the purpose of propagation rather than a critical report for the mangers of the set.

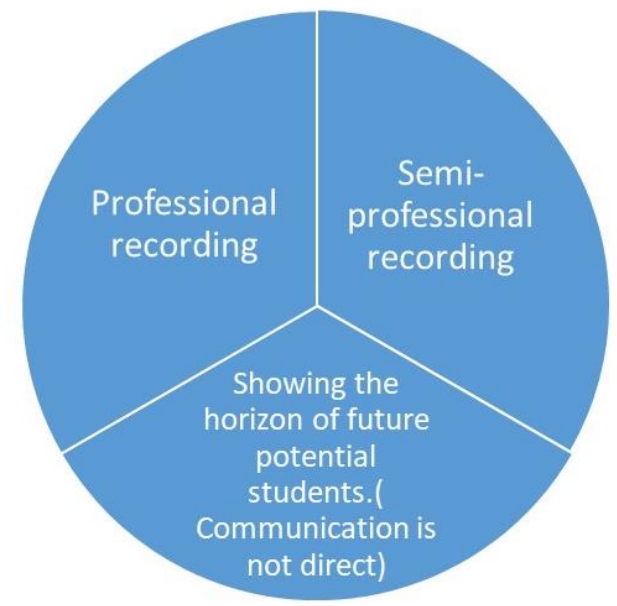

Diagram 6. Participatory products of university and student 
Walking from the grand Bazaar to Istanbul University/ Walking Tour Istanbul 2019

(Çarşısı, 2019)

In this video, the distance between Bazaar to Istanbul University has been recorded by moving instruments which states the significance of the place of Istanbul University and its centrality as a propagation strategy.

University of Michigan (Meister, 2016)

Introducing the University through interviews with students.

(Students express the positive points of studying at the university)

Tour the University of Oklahoma!

(Oklahoma, 2019)

By writing a scenario and using the students, professional filming and using the portable devices, or in other words, with the highest quality of pictorial literature, the University tries to introduce University of Oklahoma in the simple way through student's diction.

Students from Indonesia at the University of Birmingham

(University B. , 2013)

One of the other branches which have been created by the university and propagation team is to limit the students and making specialized videos about student minorities. The above video is related to the Indonesian students who are studying at University of Birmingham.

Experiences of black, Asian and minority ethnic students at University of Cambridge

(University of Cambridge, 2018) (University C. , 2018)

In line with the introducing the minority ethnic groups, and using this style of production, university tries to introduce the university as a secure environment for all minority ethnic groups and nations and for this significant ideal, it calls the students to contribute in producing the contents. Having expressed their satisfaction with presence in university, the students also invite their fellow people to pursue their studies at the mentioned university ideologically and racially.

Student life at Sharif University of Technology

In this video, efforts have been made to introduce the potentials of Tehran city from the viewpoint of culture, transportation, sport, and recreation, so that studying at Sharif University of Technology as one of the top universities in Iran which is located in the west of Tehran to be considered as a privilege. (Technology, 2019).

\section{Motion graphic productions}

Motion graphic came into existence by the Vanguardismo [Avant-garde] artists in 1920 and grew up with the graphic, T.V. and cinema. (Furio). The language of motion graphic is comprised of icons, colors and audio and musical effects and they along with texts are the constructive elements of motion graphic. Earlier, in the industrial propagation atmosphere, animation used to be employed which was a costly art. Today, with regard to the growth of software's to build animation, prefabricated frameworks and easiness in production; motion graphics enjoy a high popularity as propagation instruments accessible to universities. Motion graphic is usually used to explain an instruction, registration in one part of a site, administrative process, introducing a field of study, faculty or university, information dissemination about an event and so forth. The standard time for construction a motion graphic is estimated to be between 30 seconds to 2 minutes.

In the continuation of discussion, some examples of motion graphic in university propagation will be pointed out:

University of Jeddah motion graphic by Concord Vision

(Vision, 2018)

In this video, the University of Jeddah is introduced in Arabi by localizing the Avatars. The facilities of university, slogans and horizon of vision are publicized and at the end, the contact link of university is presented.

\section{Infographic productions:}

The spectrum of application of Infographic is very vast. Using fixed images, graphical manifestations including icons, colors, shells and different fonts; it is possible to produce statistics and figures to instructions and analyses within the framework of Infographic.

Infographic can be considered as equal as storyboard in cinema. A written plan with icon images and text which can be an instruction for the production of multimedia diverse products. Universities use this phenomenon to publicize their achievements, activities, introducing the fields, students, faculties, statistics and figures. University professors also use 
this style of productions to putting forth the scientific discussion in a popular form, by simplifying them and sharing them with the more public addressees.

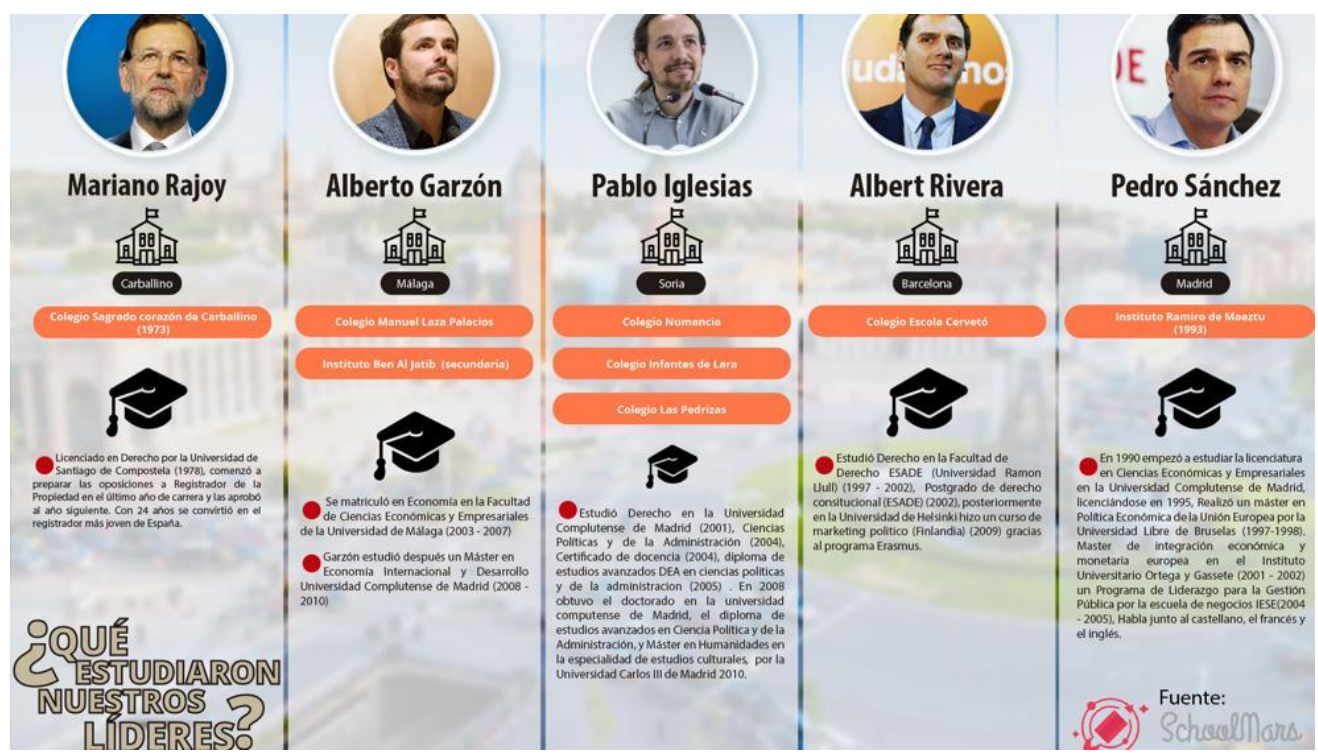

Figure 1. Infographic of the level of education of candidates for presidency in Spain

In the above Infographic, a research study has been conducted. In addition to the specifications of the candidates, in one way or another, a comparative study has been made to evaluate the level of academic education of the candidates.

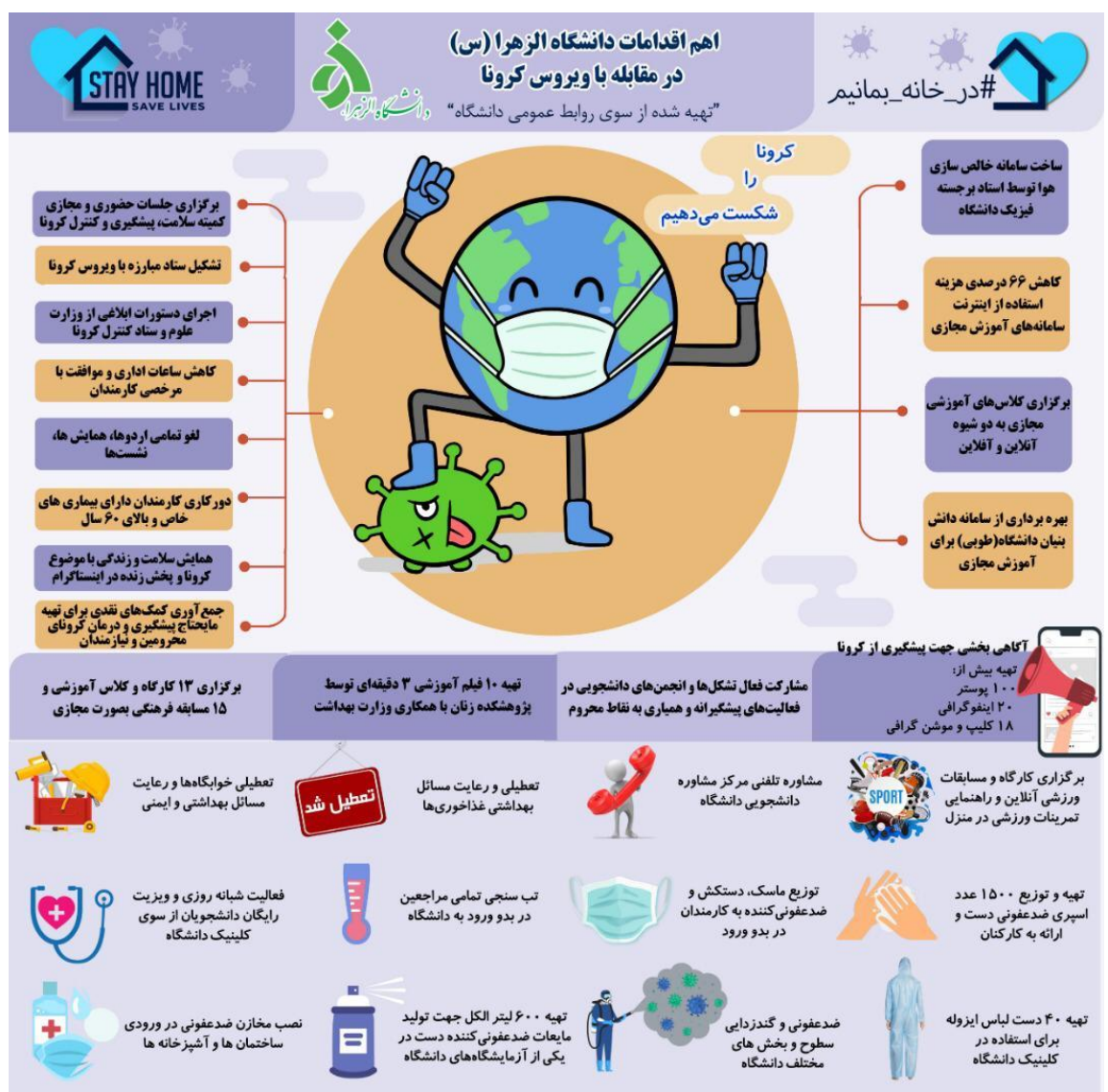

Figure 2. The most significant activities of Alzahra University in order to prevent from the spread of Corona virus

Alzahra University has listed a set of constructive activities which it had performed to face with Corona virus within the framework of above Infographic and with icon graphic and its texts, it has prepared and complied it for the public addressees. 


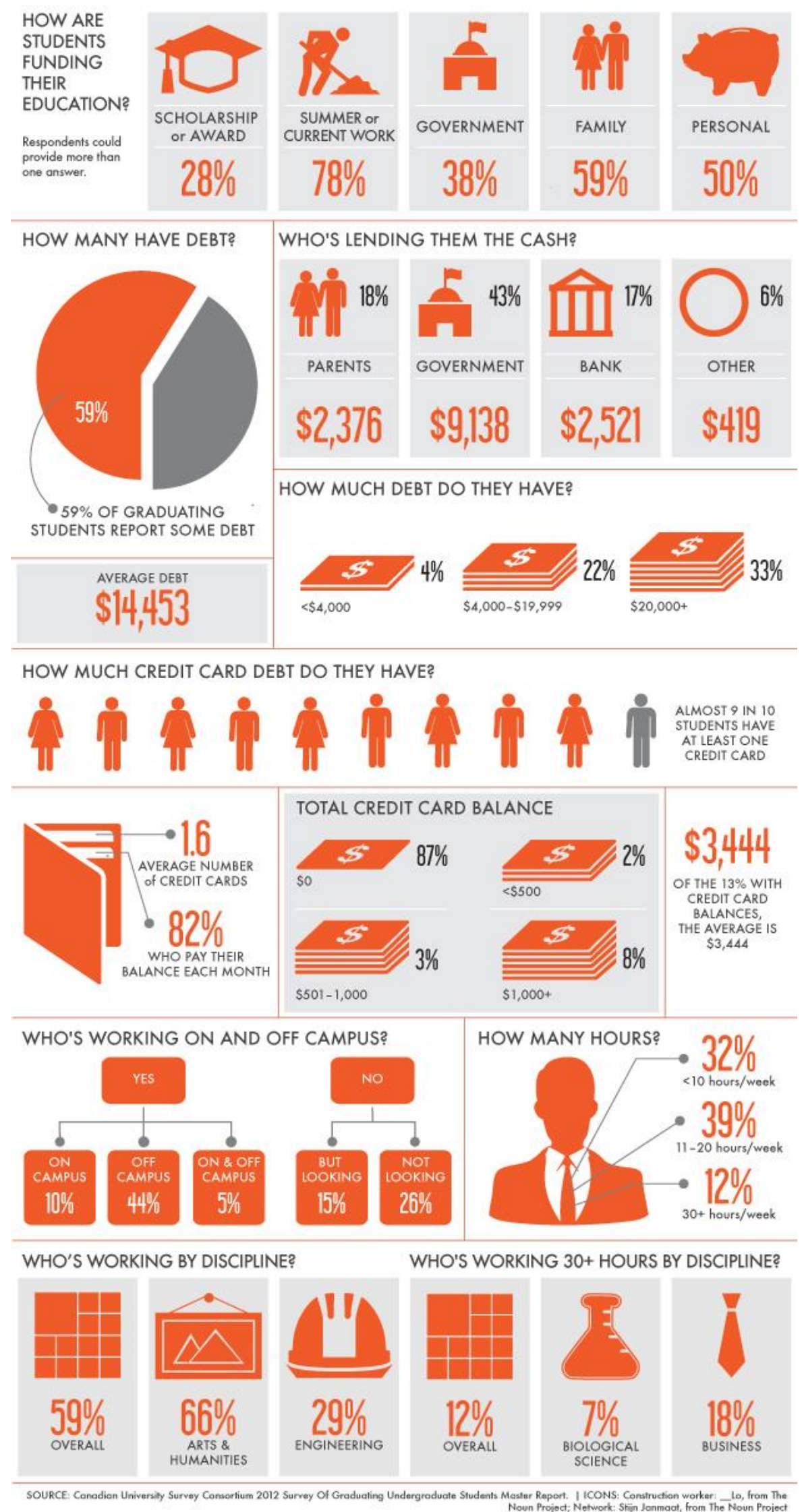

Method of payment of tuition fees by students in Canada 
The above Infographic is the data analysis related to the payment of tuition fee by students in Canada in the language of icons and colors.

\section{Concluding Remarks}

In a highly competitive and changing atmosphere of today, the use of social media is an inevitable issue. In other words, the lack of use of these facilities means to deprive universities and higher education centers from access to a vast group of addressees in particular the young generation. These conditions make us to pay attention to the phenomenon of social media literacy as an essential character in the life of university. Moreover, the administrators, planners and activists of public relations should be considered as important elements in promoting the position of university in virtual space which is in one way and another a reflection of the real environment too.

In order to be present in this environment, it is necessary to find a multilateral knowledge about it and learning its rules, to have a significant and effective presence in it. Education and gaining the instruments to be seen in this environment by using different methods and new concepts is very necessary. This visibility should be in agreement with objective realities to have a greater impact on the addressee and the presented materials to be considered as real reflection of the knowledge-based activities. The use of social media and its diverse instruments in fact will present the concept to a vast network of addresses in a more beautiful and broader form and can help with the objective of using that network and media which is the development of knowledge or absorbing new students and researchers.

The research findings show that the students spend much time in a day in different social media. The use of social media directly or indirectly is effective in their attention towards different universities. Social media can be effective in the promotion of the students' and researchers' knowledge. The reality is that the social media among the students has been converted into a part of their social and academic life and it is necessary to use this capacity to introduce the position of university. In order to achieve to this ideal, it is necessary that initially the scientific, educational and social objectives of university to be specified based on upper hand documents and strategic plans of university and then proportional with each of these objectives and considering different addressees, essential planning to be considered to be present in social media as an opportunity.

\section{Reference}

Aichner, T. (2012). The Zero Moment of Truth in Mass Customization. International Journal of Industrial Engineering and Management, 173-178.

Bahar, B. A. H. Ç. (2015). The Role of Social Media in the Promotion of University Libraries . Journal of Library and Information Sciences, 70-105.

Bieber, J. (2015, May 20). Justin Bieber Carpool Karaoke. (J. Corden, Interviewer).

Çarşısı, S. (2019, Jan 25). Walking from the Grand Bazaar to Istanbul University | Walking Tour Istanbul 2019. Retrieved from https://www.youtube.com/watch?v=00HeQ6GFobI\&t=217s

Ford, K. (2019, Apr 18). 10 Things to Know Before Coming to University of San Diego. Retrieved from Youtube: 10 Things to Know Before Coming to University of San Diego.

Furió, D. (n.d.). Análisis del estado actual de la escena audiovisual. Valencia: Furió.

Gascón, A. R. (2017). EL USO DE LAS REDES SOCIALES COMO HERRAMIENTA DE MARKETING POR PARTE DE LAS UNIVERSIDADES ESPAÑOLAS.Cartagena: Universidad Politécnica de Cartagena.

Glucksman, M. (2017). The Rise of Social Media Influencer Marketing on Lifestyle Branding: A Case Study of Lucie Fink . Elon Journal of Undergraduate Research in Communications, 77-87.

Green, A. (2014, 6 12). In bed with Adam Green \& Binki Shapiro. (http://inbedwith.org/tag/katrin-bpunkt/, Interviewer).

Guggenheim, W. R. (2011). The Evolution of Media Effects Theory: A Six-Stage Model of Cumulative Research. Communication Theory, 169-196. https://doi.org/10.1111/j.1468-2885.2011.01381.x

Meister, C. (2016, Aug 6). University of Michigan. Retrieved from https://www.youtube.com/watch?v=U-iv6CT5XSo

Oklahoma, U. O. (2019, July 22). Tour the University of Oklahoma! Retrieved from https://www.youtube.com/watch?v=EB-iakusXHE

Rebeca, C. E. L. (2016). PUBLICIDAD EN REDES SOCIALES. ¿UNA OPORTUNIDAD PARA LA PROMOCIÓN DE LA DOCENCIA EN LAS UNIVERSIDADES? Salamanca: Universidad de Salamanca.

Sison, A. (2018, May 30). Aylor Sison. Retrieved from Youtube: https://www.youtube.com/watch?v=FvhS1_vGIMM 
Sutar, N. (2019, Feb 2). Impact of Social Media in Admission Strategy for Attracting Students. Retrieved from https://www.extraaedge.com/attract-students-through-social-media/

Technology, O. S. (2019, May 21). Student Life at Sharif University of Technology. Retrieved from https://www.youtube.com/watch?v=fRghUgZVsnA

Thefannie, C. (2018, sep 23). Cindy Thefannie. Retrieved from https://www.youtube.com/watch?v=FCExiuVzCnQ

University, B. (2013, Dec 6). Students from Indonesia at the University of Birmingham. Retrieved from https://www.youtube.com/watch?v=G8txrXgZCW0

University, C. (2018, Oct 18). Experiences of Black, Asian and Minority Ethnic Students at Cambridge University. Retrieved from https://www.youtube.com/watch?v=GPJgRhyj1QE

Users, G. S. (2019, Feb 1). Global social networks ranked by number of users 2019. Retrieved from https://www.statista.com/statistics/272014/global-social-networks-ranked-by-number-of-users/

Vargus, O. (2017, Oct 21). Olivia Vargus. Retrieved from https://www.youtube.com/watch?v=PKuQHMAf6rs

Vision, C. (2018, July 24). University Of Jeddah Motion graphic BY CONCORD VISION . Retrieved from https://www.youtube.com/watch?v=nTPQShk47Eg

Zain, N. R. (2014, January 1). Agenda Setting Theory. Retrieved from file:///C:/Users/Surface/Downloads/AGENDA_SETTING_THEORY.pdf

\section{Copyrights}

Copyright for this article is retained by the author(s), with first publication rights granted to the journal.

This is an open-access article distributed under the terms and conditions of the Creative Commons Attribution license (http://creativecommons.org/licenses/by/4.0/). 